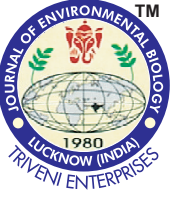

DOI : http://doi.org/10.22438/jeb/39/5/MRN-724

\title{
Soil properties and productivity of rainfed finger millet under conservation tillage and nutrient management in Eastern dry zone of Karnataka
}

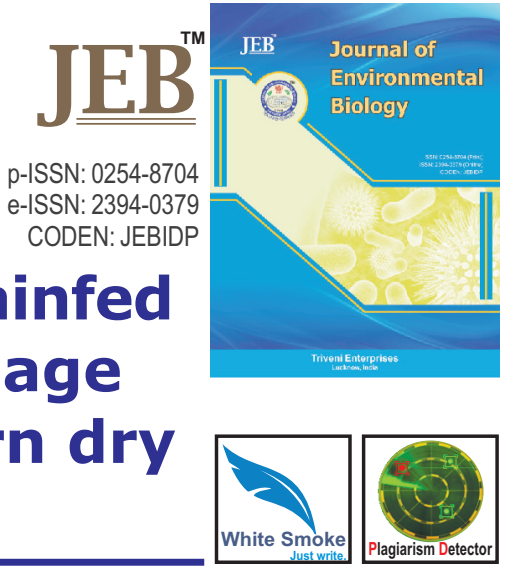

\section{Authors Info \\ V. Hatti*, B.K. Ramachandrappa, Mudalagiriyappa, A. Sathish and M.N. Thimmegowda \\ Department of Agronomy, AICRP on Dryland Agriculture, University of Agricultural Sciences, Gandhi Krishi Vijnana Kendra, Bengaluru- 560 065, India}

${ }^{*}$ Corresponding Author Email : veereshshatti@gmail.com

Key words

Afisols

Conservation tillage

Finger millet

Nutrient management

Soil properties

Publication Info

Paper received : 14.08 .2017

Revised received : 08.12.2017

Re-revised received : 20.12 .2017

Accepted : 27.12.2017

\begin{abstract}
Aim: Conservation agriculture practices serve as an alternative strategy to sustain agricultural production due to the growing water and nutrient deficiencies, particularly under rainfed conditions. The objective of this study was to find the effect of conservation tillage and nutrient management practices on soil health and productivity of finger millet.
\end{abstract}

Methodology: Three main plots viz., conventional tillage ( 2 ploughings +1 harrowing +2 intercultivations) - drill sowing, minimum tillage ( 1 ploughing +1 harrowing + application of isoproturon at $565 \mathrm{~g}$ a.i. ha ${ }^{-1}$ ) - drill sowing and zero tillage (glyphosate $41 \mathrm{SL}$ at $10 \mathrm{ml} \mathrm{I}^{-1}$ ) - transplanting and five sub plots viz., 100\% recommended NPK (50:40:25 kg NPK ha ${ }^{-1}$ ), 100\% recommended NPK + 7.5 tFYM ha ${ }^{-1}$, horsegram residue mulch with $100 \%$ recommended NPK, $50 \%$ recommended NPK $+25 \% \mathrm{~N}$ through FYM + Azotobacter seed treatment and fertilizers based on soil test results and were replicated thrice in split plot design. The soil physical, chemical and biological properties and yields were analyzed using standard procedures.

Results: Conventional tillage produced significantly higher grain and straw yield of finger millet (3.04 and $4.69 \mathrm{t} \mathrm{ha}^{-1}$, respectively) with significantly higher soil infiltration rate, cumulative infiltration, lower soil penetration resistance and bulk density as compared to minimum (2.61 and $\left.4.03 \mathrm{tha}^{-1}\right)$ and zero tillage (2.09 and $3.24 \mathrm{t} \mathrm{ha}^{-1}$ ). Zero tillage recorded significantly higher soil moisture content under dry spells, maximum water holding capacity, soil organic carbon, soil microbial population, microbial biomass carbon, nitrogen, urease, dehydrogenase, acid phosphatase and alkaline phosphatase enzymatic activity as compared to minimum and conventional tillage. Application of $100 \%$ recommended NPK $+7.5 \mathrm{t}$ FYM ha ${ }^{-1}$ yielded significantly higher grain and straw yields ( 3.03 and 4.69 t ha $^{-1}$ ) due to improved soil physico-chemical and biological properties as compared to other nutrient managements treatments.

Interpretation: Conventional tillage and application of $100 \%$ recommended NPK $+7.5 \mathrm{t}$ FYM ha ${ }^{-1}$ in Alfisols was effective in producing higher grain and straw yield of rainfed finger millet, along with improved soil health and productivity.

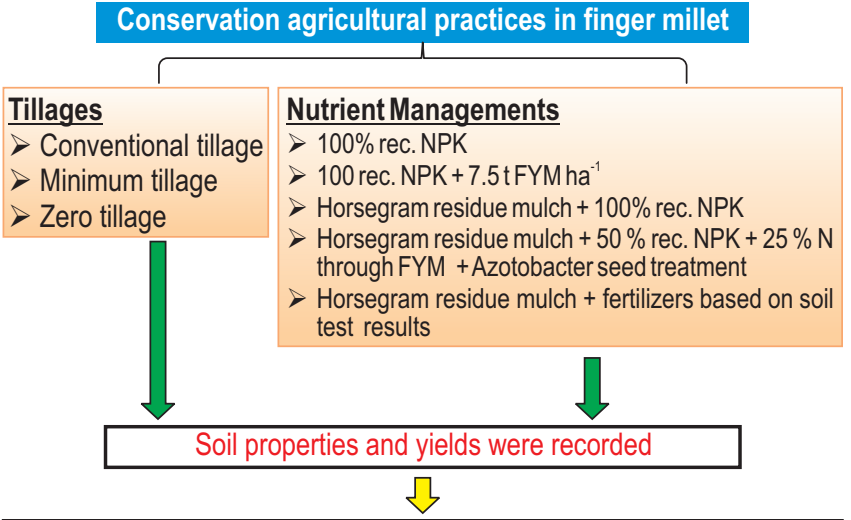

$\checkmark$ Improved soil physical properties, grain and straw yields of finger millet were observed in conventional tillage

$\checkmark$ Zero tillage recorded higher soil organic carbon, soil microbial and enzymatic activity

$\checkmark 100 \%$ recommended NPK +7.5 t FYM ha $^{-1}$ improved soil physicochemical and biological properties and realized higher grain and straw yield 


\section{Introduction}

Finger millet (Eleusine coracana (L.) Gaertn.) is a staple food for working class and an ideal food for patients suffering from diabetes as the grains contain an essential amino acid methionine has low glycemic index and no gluten, which makes it suitable for diabetics and people with digestive problems. It is an annual plant belonging to family Poaceae widely grown as a millet in the arid areas of Africa and Asia (India and Nepal). The most striking feature, which made finger millet an important dryland crop is its resilience and ability to withstand adverse weather conditions when grown in soils having poor water holding capacity. Finger millet is a predominant food crop of the Southern Karnataka (India) mainly grown under rainfed conditions in Alfisols of India. The crop grown on marginal land provides a valuable resource in times of famine and the grain tastes good and is nutritionally rich as it contains high level of calcium, iron, manganese, carbohydrates and protein apart from being good fodder for livestock. Recent studies stated that conservation agriculture practices serve as an alternative to sustain agricultural production in rainfed conditions. In India, rainfed agriculture with about 58 per cent of the cultivated area contributes 40 per cent of total food production. Even after full irrigation potential of the India is realized, half of the cultivated area will continue to be under rainfed farming. These rainfed areas are characterized by low and unstable yields, vulnerable to erratic rainfall, prone to droughts frequently amidst the declining natural resource base. Dryland farms are not only thirsty but are also hungry too for the nutrients. Hence the conservation of soil, water and other natural resources are the crucial factors for achieving sustainable production in rainfed conditions. Indiscriminate long term use of chemical fertilizers alone has not only led to imbalance of nutrients in soil, but also caused degradation of soil structure (Zaredost et al., 2014). Widespread resource degradation problems under conventional system, the need of reducing production costs, increasing profitability and making agriculture more competitive, have made the conservation issues more imperative. The Conservation agriculture technologies are said to be efficient for improving production and income, and addressing the emerging problems associated with conventional intensive tillage based agriculture (Singh et al., 2017). The role of conservation tillage practices in conserving soil moisture, with the subsequent effect on crop yields, has also been observed in Indian conditions (Kar and Kumar, 2009). Reducing tillage positively influences several aspects of the soil, whereas excessive and unnecessary tillage operations also cause harmful effects on soil. Soil tillage has major influence on soil bulk density, penetration resistance, water intake, storage and extraction of water from the soil by the plant roots and on the microbial activity, which influences soil aeration, moisture and temperature (Singh et al., 2014). Since the crop stand depends to a great extent on the emergence of sown seeds, it is essential to provide soil physical conditions conducive for germination and seedling emergence through tillage. Hence, reducing the tillage intensity is a major practice, which needs to be evaluated under various crops and cropping systems under Indian ecological conditions for their viability. Therefore, a field experiment was conducted to study the effect of conservation tillage and nutrient management practices on soil physical, chemical and biological properties in relation to Alfisols in rainfed finger millet at Eastern dry zone of Karnataka.

\section{Materials and Methods}

A field experiment was conducted to study the effect of conservation tillage and nutrient management practices on physical, chemical and biological properties of Alfisols soil in rainfed finger millet crop during kharif 2014 and 2015 atAICRP on Dry Land Agriculture Project, University of Agricultural Sciences, GKVK, Bengaluru. The experiment was conducted at the Eastern dry zone of Karnataka at $12^{\circ} 58^{\prime} \mathrm{N}$ latitude and $75^{\circ} 35^{\prime} \mathrm{E}$ longitude, $930 \mathrm{~m}$ amsl. The soil type of the experimental site belongs to Vijayapura series and represents typical lateritic area of Bengaluru plateau. These soils were deep, yellowish red, lateritic, red sandy clay loam with good drainage.

The texture of soil was red sandy clay loam $(33.20 \%$ coarse sand, $36.40 \%$ fine sand, $7.00 \%$ silt and $23.00 \%$ clay). The soils were acidic, low in organic carbon, available nitrogen, potassium and medium in available phosphorous. The details of initial soil physical, chemical and biological properties were determined and the methods followed for determination are given in Table 1. The experiment was conducted under split plot design with three different intensities of tillage systems in main plots viz., $\mathrm{T}_{1}$ : conventional tillage (2 ploughings +1 harrowing +2 intercultivations at 25 and 50 days after sowing) with drill sown finger millet, $\mathrm{T}_{2}$ : minimum tillage (1 ploughing +1 harrowing + application of pre-emergence herbicide - isoproturon at $565 \mathrm{~g}$ a.i. $\mathrm{ha}^{-1}$ ) - drill sown finger millet and $\mathrm{T}_{3}$ : zero tillage (glyphosate $41 \mathrm{SL}$ at $10 \mathrm{ml} \mathrm{l}^{-1}$ at 15 days before transplanting) with transplanted finger millet at 25 days after sowing (DAS) and five nutrient management practices in sub plots i.e., $\mathrm{N}_{1}: 100 \%$ recommended NPK (50:40:25 kg NPK ha $\left.{ }^{-1}\right), \mathrm{N}_{2}: 100 \%$ recommended NPK + $7.5 \mathrm{t}$ $\mathrm{FYM} \mathrm{ha}^{-1}, \mathrm{~N}_{3}$ : horsegram residue mulch $+100 \%$ recommended $\mathrm{NPK}, \mathrm{N}_{4}$ : horsegram residue mulch $+50 \%$ recommended NPK + $25 \% \mathrm{~N}$ through FYM + Azotobacter seed treatment and $\mathrm{N}_{5}$ : horsegram residue mulch + fertilizers based on soil test results and replicated thrice. During both the seasons, the soil was found low in available $\mathrm{N}, \mathrm{K}_{2} \mathrm{O}$ and medium in available $\mathrm{P}_{2} \mathrm{O}_{5}$, hence $130 \% \mathrm{~N}, \mathrm{~K}_{2} \mathrm{O}$ and $100 \%$ recommended $\mathrm{P}_{2} \mathrm{O}_{5}$ were applied in $\mathrm{N}_{5}$ treatment. The pre-emergence herbicide isoproturon $75 \mathrm{WP}$ at $565 \mathrm{~g}$ a.i. ha ${ }^{-1}$ was applied in minimum tillage plots two DAS using Knapsack sprayer with wide flood nozzle 78 with a spray volume of $750 \mathrm{I} \mathrm{ha}{ }^{-1}$. The post-emergence herbicide glyphosate was applied in the zero tillage plots at 15 days before transplanting $i$. e., glyphosate $41 \mathrm{SL}$ at $10 \mathrm{ml} \mathrm{l}^{-1}$ using Knapsack sprayer with wide flood nozzle 40 with a spray volume of $500 \mathrm{I} \mathrm{ha}^{-1}$ at the active green stage of weeds. The ploughing and harrowing operations 
Table 1 : Physical, chemical and biological properties of soil before initiation of experiment

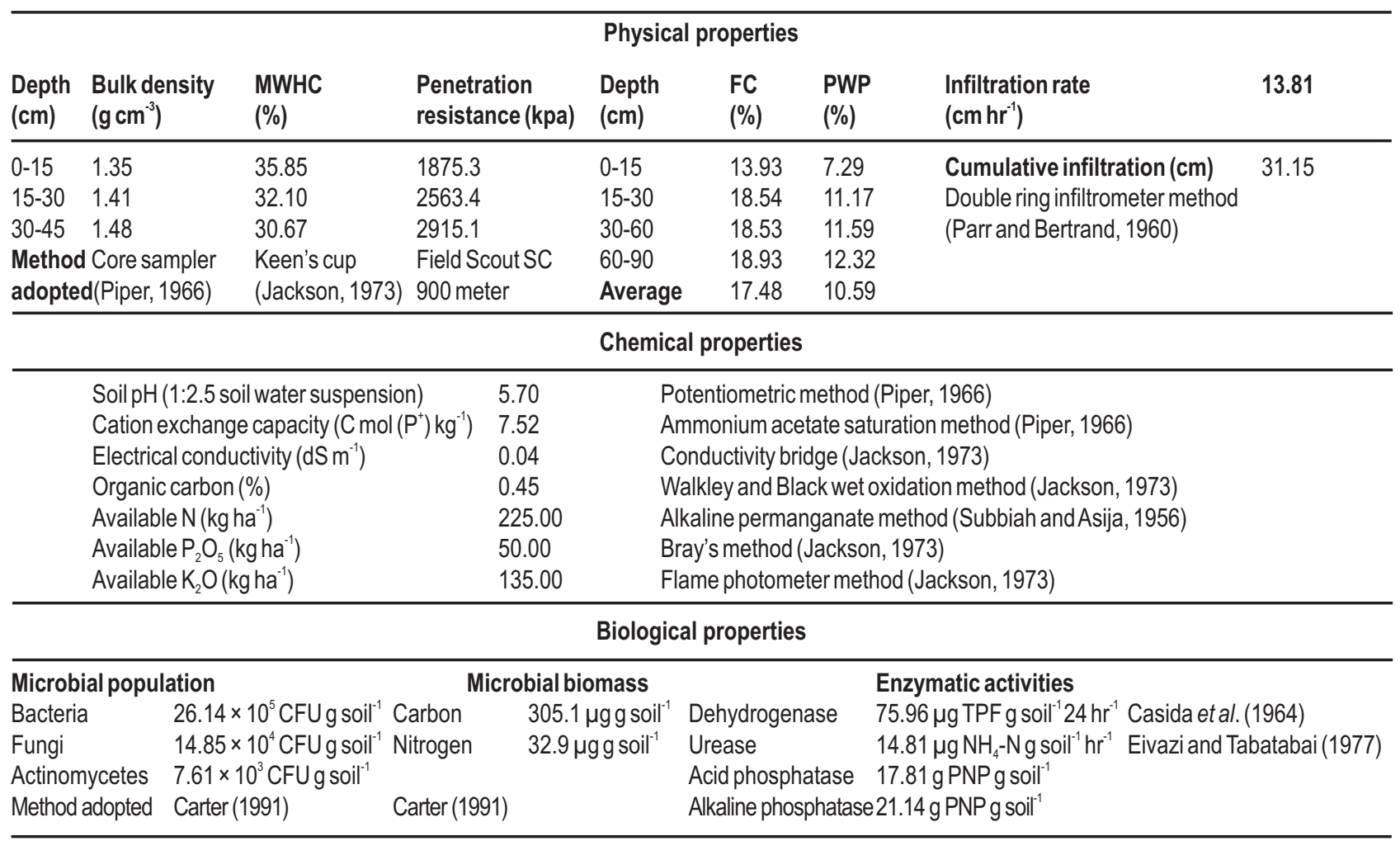

were done using tractor drawn cultivator and disc harrow, and intercultivations were done using bullock drawn blade hoe at 25 and 50 DAS as per treatments.

The finger millet variety of GPU-28 was sown/ transplanted at a spacing of $30 \mathrm{~cm} \times 10 \mathrm{~cm}$ using a seed rate of 10 $\mathrm{kg} \mathrm{ha}^{-1}$ on 9 and 10 August during 2014 and 2015, respectively. On the same date, finger millet was sown in the nursery and seedlings were transplanted at 25 DAS to the main field after light irrigation $(5 \mathrm{~mm})$ to overcome the transplanting shock. The fertilizer sources used were urea, DAP and MOP. 50 per cent of recommended nitrogen and entire phosphorus and potassium were applied at the time of sowing and remaining 50 per cent of nitrogen was applied as top dress at 30 DAS. The horsegram (Dolichos biflorus L.) seeds of variety PHG-9 were broadcasted at $50 \mathrm{~kg} \mathrm{ha}^{-1}$ in first fortnight of May with pre-monsoon rains in respective treatment plots for mulching and harvested at 60 DAS and was mulched in between the rows of fully established finger millet (During 2014, uniform quantity of $0.97 \mathrm{t} \mathrm{ha}^{-1}$ dry horsegram biomass was applied as per the treatments. And during 2015, horsegram biomass produced in respective treatments was applied i. e., $\left.\mathrm{N}_{3}-1.04 \mathrm{t} \mathrm{ha}^{-1}, \mathrm{~N}_{4}-0.95 \mathrm{t} \mathrm{ha}^{-1}, \mathrm{~N}_{5}-1.16 \mathrm{t} \mathrm{ha}^{-1}\right)$. The composition of horsegram biomass was $0.50 \% \mathrm{~N}, 0.15 \% \mathrm{P}_{2} \mathrm{O}_{5}$ and $0.39 \% \mathrm{~K}_{2} \mathrm{O}$. The seeds were treated with Azotobcater (nitrogen fixing biofertilizer) and while transplanting, the root dipping of seedlings in Azotobcater solution was done as per the treatments. The calculated amount of farm yard manure was incorporated into the soil fifteen days before sowing as per the treatments. The FYM on $\mathrm{N}$ basis was applied by considering the $\mathrm{N}$ content of FYM i. e., $0.5 \%$. (The composition of FYM was $0.50 \%$ $\mathrm{N}, 0.21 \% \mathrm{P}_{2} \mathrm{O}_{5}$ and $0.50 \% \mathrm{~K}_{2} \mathrm{O}$ ). In places where the finger millet seeds were failed to germinate and excess populations, the gap filling and thinning were done at $15 \mathrm{DAS}$, respectively to maintain optimum plant population and intra row spacing.

The total amount of rainfall received was more than normal in both the years as 994.5 and 1070.5 mm during 2014 and 2015, respectively. The crop growth period was from May to December in both the seasons (horsegram-finger millet) and also all other weather parameters were normal during both the years. The previous crop grown at the experimental site was finger millet + pigeonpea intercropping during Kharif 2013 and left fallow during Rabi and summer. During the second season of the experiment, one protective irrigation $(10.2 \mathrm{~mm})$ was given during long dry spell on 27-10-2015. The crop was harvested on 12-122014 and 03-12-2015. The grain and straw weight were recorded and converted into tha ${ }^{-1}$.

The soil moisture content during dry spells was estimated using gravimetric method and soil moisture tensions were worked out using soil moisture characteristic curve developed through using pressure membrane apparatus (Fig. 1). The soil temperature during dry periods was measured using $10 \mathrm{~cm}$ soil thermometer during $14.00 \mathrm{hrs}$. For chemical analysis of soil, soil samples were collected in the beginning and after the harvest of individual plots of the experimental field and analyzed to estimate 


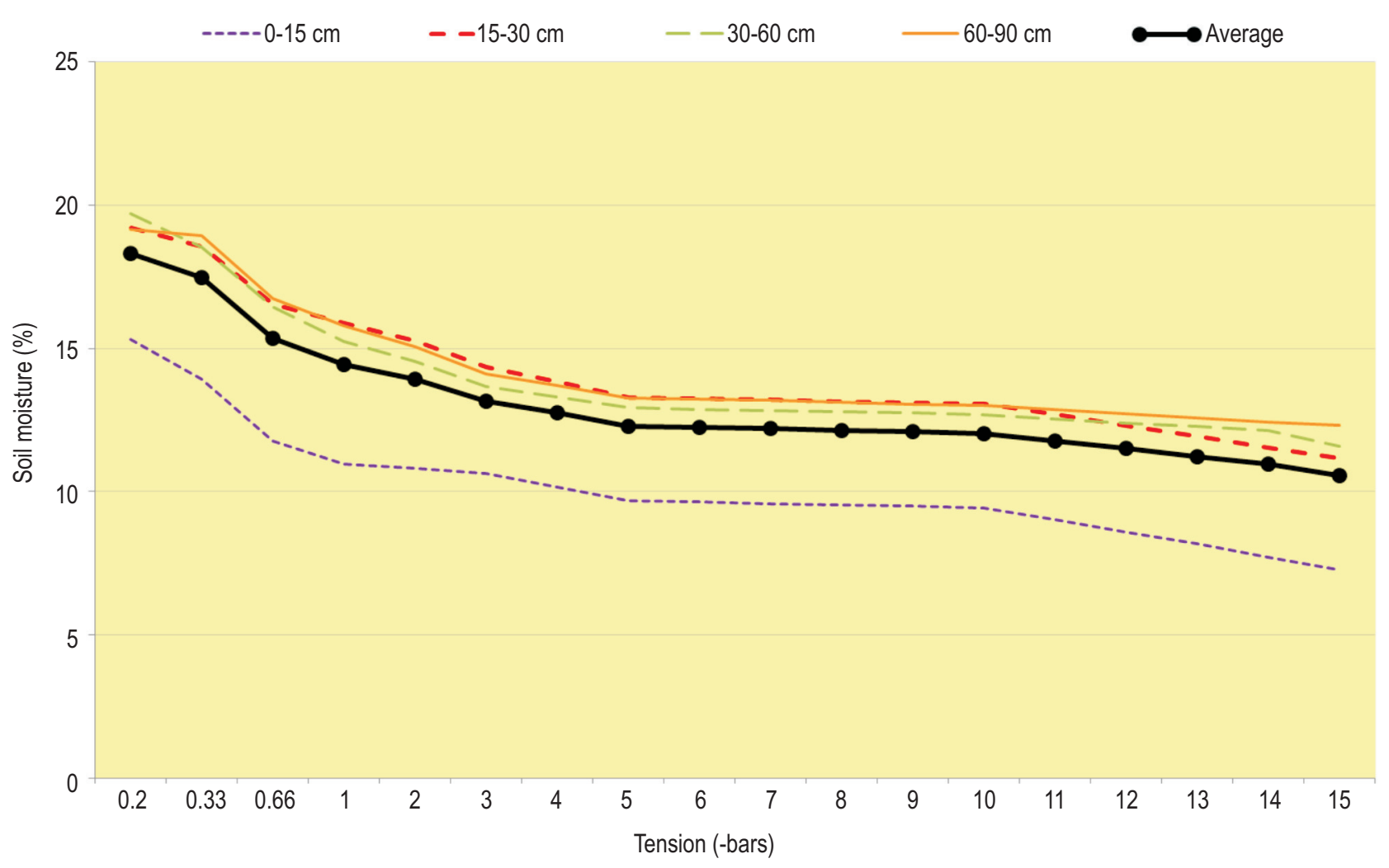

Fig. 1 : Soil moisture characteristic curve of soil at experimental site atAICRP for Dryland Agriculture, GKVK, UAS, Bengaluru

soil reaction $(\mathrm{pH})$, electrical conductivity $(\mathrm{EC})$, organic carbon $(\mathrm{OC})$ and available $\mathrm{N}, \mathrm{P}_{2} \mathrm{O}_{5}$ and $\mathrm{K}{ }_{2} \mathrm{O}$. The experimental data on soil properties and yield of finger millet were subjected to Fisher's method of Analysis of variance (ANOVA) as given by Gomez and Gomez (1984). The pooled analysis was also done for soil chemical properties, grain and straw yield. All the data were analyzed and the results were presented and discussed at a probability level of five per cent and correlation study was done as suggested by Gomez and Gomez (1984).

\section{Results and Discussion}

There is a negative correlation between soil moisture content and soil moisture tension (Michael, 2009) as indicated in Fig. 1. Zero tillage recorded significantly higher soil moisture content (Table 2) during different dry spells (14.63 to $15.42 \%$ during 2014 and 14.56 to $14.95 \%$ during 2015) with lower soil moisture tension (0.56 to 2.13 -bars 2014 and 1.45 to 2.72 -bars during 2015) as compared to minimum tillage. Whereas, comparatively lower soil moisture content was observed in conventional tillage (11.34 to 12.18 during 2014 and 11.52 to $11.97 \%$ during 2015 ) with higher soil moisture tension (7.48 to 9.29 -bars during 2014 and 8.32 to 10.21 -bars during 2015). The higher soil moisture content under zero tillage was attributed to the presence of previous crop stubbles and dense cover of weeds on the soil surface due to poor weed control under zero tillage in contrast to faster evaporation of soil moisture due to intercultivation and poor weed cover on the soil surface in conventional tillage (Sessiz et al., 2010).

Among nutrient management practices, horsegram residue mulch $+50 \%$ recommended NPK $+25 \% \mathrm{~N}$ through FYM + Azotobacter seed treatment had recorded significantly higher soil moisture content during different dry spells ( 15.11 to $15.88 \%$ 2014 and 14.82 to $15.38 \%$ during 2015) with concurrent lower soil moisture tension followed by horsegram residue mulch + fertilizers based on soil test results, horsegram residue mulch + $100 \%$ recommended NPK, $100 \%$ recommended NPK + 7.5 tFYM ha ${ }^{-1}$ in the decreasing order.

These higher soil moisture contents in these mulching treatments were due to restricted soil moisture evaporation loss by horsegram residue mulch covering on soil surface. Further, higher soil moisture content observed under FYM applied treatments was also attributed to reduced soil bulk density and absorption and storage of more moisture. And significantly lower soil moisture content under 100\% recommended NPK was attributed to lack of surface mulching and use of organic manure. These outcomes corroborated with the findings of Spehia et al. (2012). However, no significant difference in soil moisture content was observed under interactions of tillage and nutrient management practices. The conventional tillage realized 
Table 2 : Mean soil moisture content and soil moisture tension during dry periods at different stages of finger millet as influenced by tillage and nutrient management practices

\begin{tabular}{|c|c|c|c|c|c|c|c|c|c|c|}
\hline \multirow[t]{2}{*}{ Treatment } & \multicolumn{5}{|c|}{$\begin{array}{l}\text { Mean soil moisture content of different } \\
\text { depths }(\%)\end{array}$} & \multicolumn{5}{|c|}{$\begin{array}{l}\text { Mean soil moisture tension of different depths } \\
\qquad \text { (-bars) }\end{array}$} \\
\hline & $11-11-14$ & $29-11-14$ & $08-12-14$ & $22-10-15$ & $31-10-15$ & $11-11-14$ & $29-11-14$ & $08-12-14$ & $22-10-15$ & $31-10-15$ \\
\hline \multicolumn{11}{|c|}{ Tillage practices } \\
\hline $\mathrm{T}_{1}$ & 12.18 & 12.15 & 11.34 & 11.97 & 11.52 & 7.48 & 7.76 & 9.29 & 8.32 & 10.21 \\
\hline $\mathrm{T}_{2}$ & 13.53 & 13.71 & 12.92 & 13.39 & 12.96 & 2.80 & 4.32 & 6.59 & 4.68 & 5.09 \\
\hline $\mathrm{T}_{3}$ & 14.99 & 15.42 & 14.63 & 14.95 & 14.56 & 1.10 & 0.56 & 2.13 & 1.45 & 2.72 \\
\hline S.Em \pm & 0.16 & 0.27 & 0.32 & 0.26 & 0.27 & NA & NA & NA & NA & NA \\
\hline CD at $5 \%$ & 0.61 & 1.04 & 1.27 & 1.03 & 1.07 & & & & & \\
\hline \multicolumn{11}{|c|}{ Nutrient management practices } \\
\hline $\mathrm{N}_{1}$ & 11.50 & 11.45 & 10.83 & 11.33 & 11.08 & 9.60 & 9.22 & 11.90 & 9.96 & 11.55 \\
\hline $\mathrm{N}_{2}$ & 12.56 & 12.78 & 12.05 & 12.57 & 12.26 & 6.91 & 8.63 & 8.03 & 6.40 & 7.38 \\
\hline $\mathrm{N}_{3}$ & 13.95 & 14.18 & 13.31 & 13.83 & 13.37 & 2.14 & 3.69 & 4.61 & 2.43 & 4.44 \\
\hline $\mathrm{N}_{4}$ & 15.52 & 15.88 & 15.11 & 15.38 & 14.82 & 0.69 & 1.20 & 1.60 & 0.62 & 1.81 \\
\hline $\mathrm{N}_{5}$ & 14.31 & 14.51 & 13.50 & 14.06 & 13.53 & 1.86 & 2.45 & 4.31 & 1.85 & 4.17 \\
\hline S.Em \pm & 0.14 & 0.23 & 0.33 & 0.22 & 0.25 & NA & NA & NA & NA & NA \\
\hline CD at $5 \%$ & 0.41 & 0.67 & 0.95 & 0.64 & 0.74 & & & & & \\
\hline \multicolumn{11}{|c|}{ Interaction } \\
\hline \multicolumn{11}{|c|}{$\mathrm{N}$ at same level of $\mathrm{T}$} \\
\hline S.Em \pm & 0.24 & 0.40 & 0.56 & 0.38 & 0.44 & NA & NA & NA & NA & NA \\
\hline CD at $5 \%$ & NS & NS & NS & NS & NS & & & & & \\
\hline \multicolumn{11}{|c|}{ T at same or different level of $\mathrm{N}$} \\
\hline S.Em \pm & 0.27 & 0.44 & 0.60 & 0.43 & 0.48 & NA & NA & NA & NA & NA \\
\hline CD at $5 \%$ & NS & NS & NS & NS & NS & & & & & \\
\hline
\end{tabular}

Note: CD-Critical difference, NS-Non significant, NA-Not analysed. Mean soil moisture content of different depths i. e., 0-15, 15-30, 30-60 and 60-90 cm; Dry periods:- 11-11-2014: Milking stage in 2014, 29-11-2014: Physiological maturity stage in 2014, 08-12-2014: Harvest stage in 2014, 22-10-2015: Flowering stage in 2015 and 31-10-2015 at flowering stage in 2015

significantly higher infiltration rate $\left(15.89 \mathrm{~cm} \mathrm{hr}^{-1}\right)$, cumulative infiltration $(36.04 \mathrm{~cm})$, lower soil bulk density $(1.33,1.40$ and 1.47 $\mathrm{g} \mathrm{cm}^{-3}$ at $0-15,15-30$ and $30-45 \mathrm{~cm}$ depths, respectively) and soil penetration resistance $(1201.9,1314.8$ and $1490.7 \mathrm{kpa}$ at $0-15$, $15-30$ and $30-45 \mathrm{~cm}$ depths, respectively) followed by minimum tillage and zero tillage (Fig. 2 and Table 3 ).

The ploughing and subsequent intercultivations in conventional tillage had reduced the bulk density up to $45 \mathrm{~cm}$ soil depth as a result of loosened soil particles resulting in improved infiltration rate, as well as cumulative infiltration apart from lowered soil penetration resistance up to $45 \mathrm{~cm}$ soil depth. The negative relation between bulk density versus infiltration rate and cumulative infiltration ranged from - 0.869 to -0.925 and regression studies indicated that there was increase in infiltration rate and cumulative infiltration by $12.60 \mathrm{~cm} \mathrm{hr}^{-1}$ and $26.89 \mathrm{~cm}$, respectively for every gram $\mathrm{cm}^{-3}$ decrease in bulk density at 0-15 $\mathrm{cm}$ soil depth (Table 7). Positive correlation between bulk density and soil penetration resistance $i$. e., the regression equations revealed that for every gram $\mathrm{cm}^{-3}$ increase in bulk density at 0-15 $\mathrm{cm}$ soil depth has led to increase in penetration resistance by $2804.77 \mathrm{kpa}$. The similar trend was also noticed at $15-30$ and 30-
$45 \mathrm{~cm}$ soil depths (Alvarez and Steinbach, 2009). This was followed by minimum tillage due to proportionate decrease in tillage intensity. Whereas, significantly lower soil infiltration rate, cumulative infiltration and significantly higher bulk density at different depths in zero tillage was ascribed to increased soil compaction as a result of no soil disturbance, ploughing, soil crusting as indicated by higher soil penetration resistance.

However, the maximum water holding capacity of soil (Fig. 3) was found higher in zero tilled plots (43.10, 38.36 and $35.36 \%$ at $0-15,15-30$ and $30-45 \mathrm{~cm}$, respectively), which was due to higher soil organic carbon witnessed $(0.56 \%)$ followed by minimum and conventional tillage due to their lower organic carbon content $(0.50 \%$ and $0.46 \%$, respectively) as indicated by positive and higher correlation coefficient values (Table 7), which ranged between 0.657 at $0-15 \mathrm{~cm}$ to 0.924 at $30-45 \mathrm{~cm}$ soil depths. Further, regression studies revealed that for every per cent increase in soil organic carbon, there would be an increase in the maximum water holding capacity of soil by $66.53,59.17$ and $22.59 \%$ at $0-15,15-30$ and $30-45 \mathrm{~cm}$ soil depths (Manivannan et al., 2009). The lower maximum water holding capacity under conventional tillage with lower soil organic carbon content 
Table 3 : Bulk density $(\mathrm{BD})$ of soil after harvest of second season finger millet and soil temperature $\left({ }^{\circ} \mathrm{C}\right)$ during crop growth period under dry spells as influenced by tillage and nutrient management practices

\begin{tabular}{|c|c|c|c|c|c|c|c|c|c|c|c|c|c|c|}
\hline \multirow[t]{2}{*}{ Treatment } & \multicolumn{3}{|c|}{$\begin{array}{l}\mathrm{BD}\left(\mathrm{g} \mathrm{cm}^{-3}\right) \text { at different } \\
\text { soil depth }(\mathrm{cm})\end{array}$} & \multicolumn{7}{|c|}{ Soil temperature (2014) } & \multicolumn{4}{|c|}{ Soil temperature (2015) } \\
\hline & $0-15$ & $15-30$ & $30-45$ & $\begin{array}{l}30^{\text {th }} \\
\text { Aug }\end{array}$ & $\begin{array}{l}18^{\text {th }} \\
\text { Sept }\end{array}$ & $\begin{array}{l}5^{\text {th }} \\
\text { Oct }\end{array}$ & $\begin{array}{l}16^{\text {th }} \\
\text { Oct }\end{array}$ & $\begin{array}{l}11^{\text {th }} \\
\text { Nov }\end{array}$ & $\begin{array}{l}27^{\text {th }} \\
\text { Nov }\end{array}$ & $\begin{array}{l}9^{\text {th }} \\
\text { Dec }\end{array}$ & $\begin{array}{l}20^{\text {th }} \\
\text { Sept }\end{array}$ & $\begin{array}{l}15^{\text {th }} \\
\text { Oct }\end{array}$ & $\begin{array}{l}29^{\text {th }} \\
\text { Oct }\end{array}$ & $\begin{array}{l}29^{\text {th }} \\
\text { Nov }\end{array}$ \\
\hline \multicolumn{15}{|c|}{ Tillage practices } \\
\hline $\mathrm{T}_{1}$ & 1.33 & 1.40 & 1.47 & 30.6 & 33.5 & 32.4 & 34.0 & 31.4 & 31.4 & 33.5 & 31.1 & 33.7 & 34.6 & 28.8 \\
\hline $\mathrm{T}_{2}$ & 1.45 & 1.52 & 1.59 & 27.1 & 29.7 & 28.7 & 29.4 & 27.5 & 27.8 & 29.7 & 26.9 & 29.2 & 29.9 & 25.1 \\
\hline $\mathrm{T}_{3}$ & 1.58 & 1.67 & 1.74 & 24.1 & 25.5 & 24.6 & 25.7 & 23.9 & 24.1 & 25.4 & 23.4 & 25.4 & 26.3 & 21.7 \\
\hline S.Em \pm & 0.02 & 0.03 & 0.03 & 0.6 & 0.8 & 0.8 & 0.8 & 0.7 & 0.8 & 0.8 & 0.8 & 0.8 & 0.8 & 0.7 \\
\hline CD at $5 \%$ & 0.10 & 0.10 & 0.11 & 2.3 & 3.2 & 3.2 & 3.1 & 2.9 & 3.0 & 3.1 & 3.0 & 3.0 & 3.2 & 2.8 \\
\hline \multicolumn{15}{|c|}{ Nutrient management practices } \\
\hline $\mathrm{N}_{1}$ & 1.67 & 1.75 & 1.65 & 28.4 & 30.8 & 29.7 & 30.8 & 29.0 & 29.0 & 30.7 & 28.4 & 30.9 & 31.6 & 26.1 \\
\hline $\mathrm{N}_{2}$ & 1.23 & 1.30 & 1.55 & 31.3 & 33.9 & 32.8 & 33.9 & 31.6 & 32.0 & 33.9 & 31.6 & 34.4 & 34.9 & 29.0 \\
\hline $\mathrm{N}_{3}$ & 1.53 & 1.61 & 1.62 & 25.4 & 27.7 & 27.0 & 28.2 & 25.8 & 25.9 & 27.5 & 25.0 & 27.2 & 28.5 & 23.9 \\
\hline $\mathrm{N}_{4}$ & 1.37 & 1.44 & 1.57 & 25.7 & 28.0 & 26.9 & 28.0 & 26.0 & 26.0 & 27.6 & 25.3 & 27.5 & 28.3 & 23.7 \\
\hline $\mathrm{N}_{5}$ & 1.49 & 1.56 & 1.61 & 25.5 & 27.6 & 26.7 & 27.6 & 25.7 & 26.0 & 27.6 & 25.1 & 27.3 & 28.1 & 23.4 \\
\hline S.Em \pm & 0.03 & 0.03 & 0.04 & 0.6 & 0.7 & 0.7 & 0.7 & 0.7 & 0.8 & 0.7 & 0.8 & 0.9 & 0.8 & 0.6 \\
\hline CD at $5 \%$ & 0.09 & 0.10 & NS & 1.8 & 2.1 & 2.2 & 2.0 & 1.9 & 2.5 & 2.1 & 2.5 & 2.6 & 2.3 & 1.8 \\
\hline \multicolumn{15}{|c|}{ Interaction } \\
\hline \multicolumn{15}{|c|}{$\mathrm{N}$ at same level of $\mathrm{T}$} \\
\hline S.Em \pm & 0.06 & 0.06 & 0.06 & 1.1 & 1.3 & 1.3 & 1.2 & 1.1 & 1.5 & 1.3 & 1.5 & 1.5 & 1.4 & 1.1 \\
\hline CD at $5 \%$ & NS & NS & NS & NS & NS & NS & NS & NS & NS & NS & NS & NS & NS & NS \\
\hline \multicolumn{15}{|c|}{ Tat same or different level of $\mathrm{N}$} \\
\hline S.Em \pm & 0.06 & 0.06 & 0.06 & 1.1 & 1.4 & 1.4 & 1.3 & 1.2 & 1.5 & 1.4 & 1.5 & 1.6 & 1.5 & 1.2 \\
\hline CD at $5 \%$ & NS & NS & NS & NS & NS & NS & NS & NS & NS & NS & NS & NS & NS & NS \\
\hline
\end{tabular}

Note: CD-Critical difference, NS-Non significant, BD-Bulk density, Aug-August, Sept-September, Oct-October, Nov-November, Dec-December

$(0.46 \%)$ was due to faster degradation of organic matter by intensive ploughing operations and exposure of soil layers to the solar radiation.

Among different nutrient management practices, application of $100 \%$ recommended NPK + 7.5 t FYM ha-1 had significantly higher soil infiltration rate $\left(16.11 \mathrm{~cm} \mathrm{hr}^{-1}\right)$, cumulative infiltration $(37.12 \mathrm{~cm})$, maximum water holding capacity at 0-15 $\mathrm{cm}(46.74 \%), 15-30 \mathrm{~cm}(41.60 \%)$ soil depths, lower bulk density at $0-15 \mathrm{~cm}\left(1.23 \mathrm{~g} \mathrm{~cm}^{-3}\right), 15-30 \mathrm{~cm}\left(1.30 \mathrm{~g} \mathrm{~cm}^{-3}\right)$ soil depths, soil penetration resistance at $0-15 \mathrm{~cm}(1328.5 \mathrm{kpa})$ and $15-30 \mathrm{~cm}$ (1656.5 kpa ) soil depths as compared to horsegram residue mulch $+50 \%$ recommended NPK $+25 \% \mathrm{~N}$ through FYM + Azotobacter seed treatment, horsegram residue mulch + fertilizers based on soil test results, horsegram residue mulch + $100 \%$ recommended NPK and significantly lower values were observed under $100 \%$ recommended NPK. But these nutrient management practices did not significantly influenced the bulk density, maximum water holding capacity and soil penetration resistance at $30-45 \mathrm{~cm}$ soil depths. The interactions of tillage and nutrient management practices were not found significant for all the soil physical parameters. The improved soil physical properties under $100 \%$ recommended NPK + $7.5 \mathrm{t} \mathrm{FYM} \mathrm{ha}^{-1}$ was attributed to lowered soil bulk density due to the positive effects of application of farm yard manure (Chandel et al., 2017). The next best soil physical properties were recorded under mulched and FYM applied treatments due to the combined effect of organic mulching and FYM in improving the soil physical parameters. But, poor soil physical parameters under application of $100 \%$ recommended NPK were due to the application of chemical fertilizers alone without organic manures. The results are in conformity with the findings of Manivannan et al. (2009) who reported that increase in bulk density was attributed to deterioration of the structure with fertilizers, when applied alone.

The conventional tillage had recorded significantly higher soil temperature at different days in dry spells (30.6, 33.5, 32.4, $34.0,31.4,31.4,33.5^{\circ} \mathrm{C}$ on $30^{\text {th }}$ August, $18^{\text {th }}$ September, $5^{\text {th }}$ October, $16^{\text {th }}$ October, $11^{\text {th }}$ November, $27^{\text {th }}$ November, $9^{\text {th }}$ December, respectively during 2014 and $31.1,33.7,34.6,28.8^{\circ} \mathrm{C}$ on $20^{\text {th }}$ September, $15^{\text {th }}$ October, $29^{\text {th }}$ October, $29^{\text {th }}$ November, respectively during 2015) as compared to minimum and zero tillage (Table 3). These results are in line with Hugh et al. (2008) who observed lower soil temperature in no tillage as compared to 


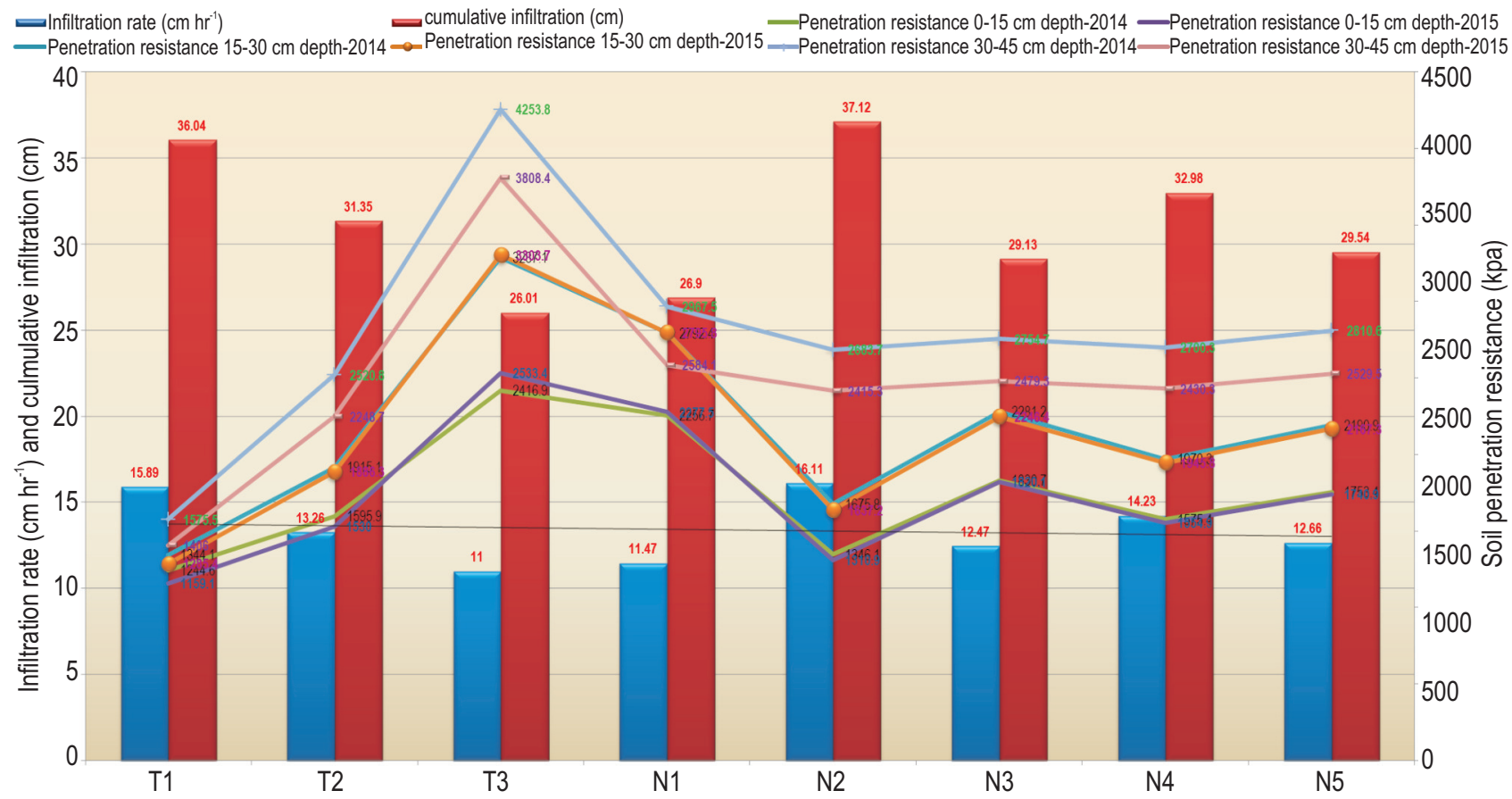

Fig. 2 : Infiltration rate $(\mathrm{cm})$, cumulative infiltration $(\mathrm{cm})$ and soil penetration resistance $(\mathrm{kpa})$ at different soil depths as influenced by tillage and nutrient management practices

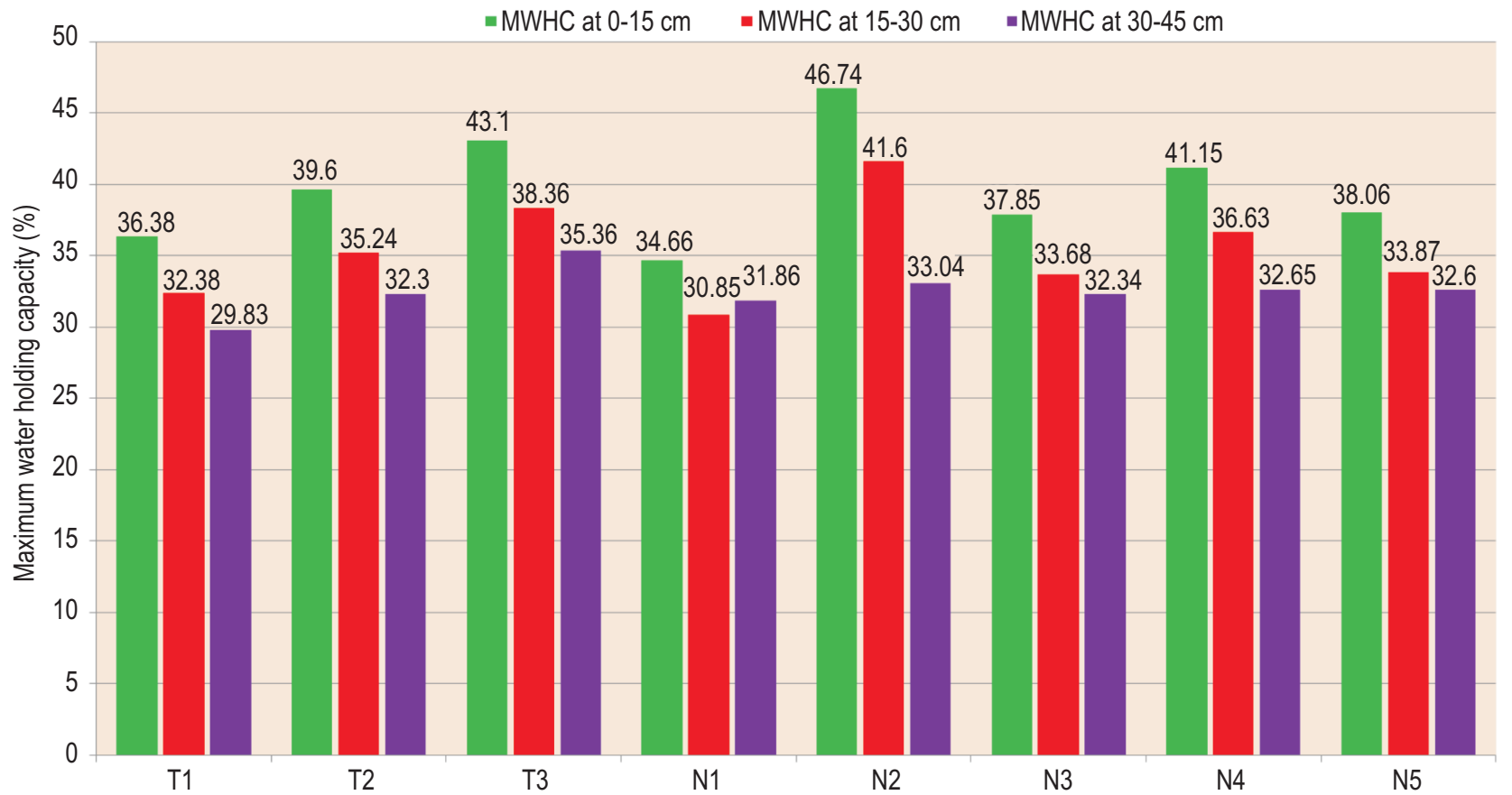

Fig. 3 : Maximum water holding capacity (\%) at different soil depths after harvest of finger millet as influenced by tillage and nutrient management practices

high tillage systems. And the lower temperature in zero tillage was due to the insulation effect of accumulated crop residues on the soil surface (Teodor et al., 2011). Whereas, application of $100 \%$ recommended NPK + 7.5 t FYM ha ${ }^{-1}$ recorded significantly higher soil temperature at different dry spells $(31.3,33.9,32.8,33.9$, $31.6,32.0,33.9^{\circ} \mathrm{C}$ on $30^{\text {th }}$ August, $18^{\text {th }}$ September, $5^{\text {th }}$ October, 
Table 4 : Soil chemical properties after harvest of finger millet as influenced by tillage and nutrient management practices

\begin{tabular}{|c|c|c|c|c|c|c|c|c|c|}
\hline \multirow[t]{2}{*}{ Treatment } & \multicolumn{3}{|c|}{$\mathrm{pH}$} & \multicolumn{3}{|c|}{$\begin{array}{l}\text { Electrical conductivity } \\
\left(\text { (ds } \mathrm{m}^{-1}\right)\end{array}$} & \multicolumn{3}{|c|}{ Organic carbon (\%) } \\
\hline & 2014 & 2015 & Pooled & 2014 & 2015 & Pooled & 2014 & 2015 & Pooled \\
\hline \multicolumn{10}{|c|}{ Tillage practices } \\
\hline $\mathrm{T}_{1}$ & 5.69 & 5.63 & 5.66 & 0.041 & 0.043 & 0.042 & 0.46 & 0.47 & 0.46 \\
\hline $\mathrm{T}_{2}$ & 5.64 & 5.58 & 5.61 & 0.044 & 0.044 & 0.044 & 0.49 & 0.50 & 0.50 \\
\hline $\mathrm{T}_{3}$ & 5.58 & 5.50 & 5.54 & 0.046 & 0.046 & 0.046 & 0.55 & 0.57 & 0.56 \\
\hline S.Em \pm & 0.05 & 0.05 & 0.04 & 0.002 & 0.002 & 0.001 & 0.01 & 0.01 & 0.01 \\
\hline CD at $5 \%$ & NS & NS & NS & NS & NS & NS & 0.05 & 0.05 & 0.03 \\
\hline \multicolumn{10}{|c|}{ Nutrient management practices } \\
\hline $\mathrm{N}_{1}$ & 5.49 & 5.43 & 5.46 & 0.045 & 0.045 & 0.045 & 0.45 & 0.46 & 0.45 \\
\hline $\mathrm{N}_{2}$ & 5.75 & 5.68 & 5.72 & 0.042 & 0.043 & 0.043 & 0.60 & 0.61 & 0.60 \\
\hline $\mathrm{N}_{3}$ & 5.53 & 5.47 & 5.50 & 0.043 & 0.044 & 0.044 & 0.46 & 0.47 & 0.47 \\
\hline $\mathrm{N}_{4}$ & 5.98 & 5.91 & 5.94 & 0.043 & 0.044 & 0.044 & 0.53 & 0.54 & 0.53 \\
\hline $\mathrm{N}_{5}$ & 5.43 & 5.36 & 5.39 & 0.045 & 0.045 & 0.045 & 0.47 & 0.48 & 0.48 \\
\hline S.Em \pm & 0.05 & 0.05 & 0.04 & 0.002 & 0.002 & 0.001 & 0.01 & 0.01 & 0.01 \\
\hline CD at $5 \%$ & 0.15 & 0.15 & 0.10 & NS & NS & NS & 0.03 & 0.03 & 0.02 \\
\hline \multicolumn{10}{|c|}{ Interaction } \\
\hline \multicolumn{10}{|c|}{ Nat same level of $\mathrm{T}$} \\
\hline S.Em \pm & 0.09 & 0.09 & 0.11 & 0.003 & 0.004 & 0.004 & 0.02 & 0.02 & 0.03 \\
\hline CD at $5 \%$ & NS & NS & NS & NS & NS & NS & NS & NS & NS \\
\hline \multicolumn{10}{|c|}{ T at same or different level of $\mathrm{N}$} \\
\hline S.Em \pm & 0.09 & 0.09 & 0.11 & 0.004 & 0.004 & 0.004 & 0.02 & 0.02 & 0.03 \\
\hline CD at $5 \%$ & NS & NS & NS & NS & NS & NS & NS & NS & NS \\
\hline
\end{tabular}

Note: CD-Critical difference, NS-Non significant

$16^{\text {th }}$ October, $11^{\text {th }}$ November, $27^{\text {th }}$ November, $9^{\text {th }}$ December, respectively during 2014 and $31.6,34.4,34.9,29.0{ }^{\circ} \mathrm{C}$ on $20^{\text {th }}$ September, $15^{\text {th }}$ October, $29^{\text {th }}$ October, $29^{\text {th }}$ November, respectively during 2015 ) followed by $100 \%$ recommended NPK. The higher soil temperature was due to release of organic acids upon decomposition, as well as no mulching effect on the soil. And significantly lower soil temperature under mulched treatments was assigned due to restriction of direct contact of radiation to the ground through interference with horsegram residue mulch. These observations follow the results of Rajan et al. (2011) who quoted that application of FYM maintains higher soil temperature under open condition, which supported better growth and crop stand by reducing mortality rate. However, soil temperature due to interactions between tillage and nutrient management practices was found to be non-significant.

Application of horsegram residue mulch + fertilizers based on soil test results, recorded significantly lower soil pH (5.39) on the account of application of more quantity of these acid forming chemical fertilizers such as urea and DAP, and was on par with $100 \%$ recommended NPK alone (5.46) and was followed by horsegram residue mulch $+100 \%$ recommended NPK (5.50), $100 \%$ recommended NPK +7.5 t FYM ha ${ }^{-1}$ (5.72). Whereas, significantly higher soil $\mathrm{pH}$ was noticed under horsegram residue mulch $+50 \%$ recommended NPK $+25 \% \mathrm{~N}$ through FYM + Azotobacter seed treatment (5.94) (Table 4). The higher and near neutral $\mathrm{pH}$ in FYM and mulched treatments was attributed to buffering action of FYM and organic mulches upon decomposition. These results were similar to the findings of Brady and Weil (2008). Different tillage practices and interaction between tillage and nutrient management practices have been found to be nonsignificant. The EC was not significantly influenced by the tillage, nutrient management practices and their interactions.

Soil organic carbon (SOC) is largely governed by the farming practice and climate. The net gain of organic carbon by soil determines soil productivity. Soil organic carbon is often defined as the soil quality indicator, especially organic carbon present on the surface soils. The zero tillage had higher SOC $(0.56 \%)$ as compared to minimum tillage $(0.50 \%)$ and conventional tillage $(0.46 \%)$. This higher SOC in zero tillage was due to degradation of crop stubbles left and no soil inversion, which was further supported by increased microbial and enzymatic activity (Table 5,6) with better soil moisture content even under dry spells (Table 2).

Among different nutrient management practices, significantly higher SOC was noticed with the application of $100 \%$ 
Table 5 : Soil microbial parameters after harvest of second season finger millet as influenced by tillage and nutrient management practices

\begin{tabular}{|c|c|c|c|c|c|}
\hline \multirow[t]{2}{*}{ Treatment } & \multicolumn{3}{|c|}{ Microbial population } & \multirow{2}{*}{$\begin{array}{l}\text { Microbial } \\
\text { biomass carbon } \\
\left(\mu g g_{\text {soil }}{ }^{-1}\right)\end{array}$} & \multirow{2}{*}{$\begin{array}{l}\text { Microbial } \\
\text { biomass nitrogen } \\
\left(\mu \mathrm{g} g \text { soil }^{-1}\right)\end{array}$} \\
\hline & $\begin{array}{l}\text { Bacteria }\left(\times 10^{5}\right. \\
\left.\text { CFU g soil }^{-1}\right)\end{array}$ & $\begin{array}{l}\text { Fungi }\left(\times 10^{4}\right. \\
\left.\text { CFUg soil }^{-1}\right)\end{array}$ & $\begin{array}{l}\text { Actinomycetes } \\
\left(\times 10^{3} \text { CFU g soil }^{-1}\right)\end{array}$ & & \\
\hline \multicolumn{6}{|c|}{ Tillage practices } \\
\hline $\mathrm{T}_{1}$ & 32.83 & 17.85 & 10.66 & 318.7 & 37.2 \\
\hline $\mathrm{T}_{2}$ & 42.19 & 22.92 & 13.68 & 407.0 & 47.5 \\
\hline $\mathrm{T}_{3}$ & 58.14 & 32.74 & 18.19 & 557.5 & 65.0 \\
\hline S.Em \pm & 1.18 & 0.76 & 0.43 & 11.1 & 1.3 \\
\hline CD at $5 \%$ & 4.63 & 3.00 & 1.68 & 43.6 & 5.1 \\
\hline \multicolumn{6}{|c|}{ Nutrient management practices } \\
\hline $\mathrm{N}_{1}$ & 36.25 & 19.48 & 11.26 & 342.0 & 39.9 \\
\hline $\mathrm{N}_{2}$ & 55.86 & 31.65 & 18.35 & 572.0 & 66.7 \\
\hline $\mathrm{N}_{3}$ & 41.10 & 22.51 & 13.03 & 387.7 & 45.2 \\
\hline $\mathrm{N}_{4}$ & 46.64 & 25.79 & 14.92 & 440.0 & 51.3 \\
\hline $\mathrm{N}_{5}$ & 42.08 & 23.08 & 13.32 & 396.9 & 46.3 \\
\hline S.Em \pm & 1.18 & 0.73 & 0.40 & 11.2 & 1.3 \\
\hline CD at $5 \%$ & 3.46 & 2.12 & 1.18 & 32.6 & 3.8 \\
\hline \multicolumn{6}{|l|}{ Interaction } \\
\hline \multicolumn{6}{|c|}{$\mathrm{N}$ at same level of $\mathrm{T}$} \\
\hline S.Em \pm & 2.05 & 1.26 & 0.70 & 19.3 & 2.26 \\
\hline CD at $5 \%$ & NS & NS & NS & NS & NS \\
\hline \multicolumn{6}{|c|}{ T at same or different level of $\mathrm{N}$} \\
\hline S.Em \pm & 2.18 & 1.36 & 0.76 & 20.6 & 2.40 \\
\hline CD at $5 \%$ & NS & NS & NS & NS & NS \\
\hline
\end{tabular}

Note: CD-Critical difference, NS-Non significant

recommended NPK + 7.5 t FYM ha ${ }^{-1}(0.60 \%)$ as compared to others due to application of FYM, which had enhanced the soil organic carbon content upon degradation. The lowest organic carbon recorded in $100 \%$ recommended NPK $(0.45 \%)$ alone was a consequence of no use of organic manure. These findings are in concurrence with Liu et al. (2013).

The population of bacteria, fungi and actinomycetes, microbial biomass carbon and nitrogen, urease, dehydrogenase, acid phosphatase and alkaline phosphatase enzyme activity in soil were significantly influenced by different tillage and nutrient management practices (Table 5, 6). Amidst different tillage practices, zero tillage had realized significantly higher population of bacteria, fungi and actinomycetes $\left(58.14 \times 10^{5}, 32.74 \times 10^{4}\right.$ and $18.19 \times 10^{3} \mathrm{CFU} g$ soil ${ }^{-1}$, respectively) and resulted in increase in soil microbial biomass carbon and nitrogen $\left(557.5 \mu \mathrm{g} \mathrm{soil}{ }^{-1}\right.$ and $65.0 \mu \mathrm{g} \mathrm{g} \mathrm{soil}{ }^{-1}$, respectively) as compared to minimum tillage and conventional tillage. The zero tillage had also recorded significantly higher urease, dehydrogenase, acid phosphatase and alkaline phosphatase activity $\left(31.76 \mu \mathrm{g} \mathrm{NH}_{4}-\mathrm{N} \mathrm{g} \mathrm{soil}^{-1} \mathrm{hr}^{-1}\right.$, $183.79 \mu \mathrm{g} \mathrm{TPF} g$ soil ${ }^{-1} 24 \mathrm{hr}^{-1}, 34.34 \mathrm{~g} \mathrm{PNP} \mathrm{g} \mathrm{soil}{ }^{-1}$ and $35.11 \mathrm{~g} \mathrm{PNP}$ $\mathrm{g} \mathrm{soil}^{-1}$, respectively) as a consequence of improved microbial population as compared to minimum tillage and conventional tillage. The increase in soil microbial activity under zero tillage was attributed to increased availability of substrate for microbes in terms of stubbles, secretion of root exudates as substrates from weeds, least soil disturbance and better soil moisture content as a result of better soil coverage by crops, as well as weeds. It also enhanced the soil microbial biomass carbon, nitrogen and enzymatic activities. The lower soil microbial activity, biomass carbon, nitrogen and resultant lower soil enzymatic activity under conventional tillage was due to clean cultivation with no residue management, lower soil organic carbon, greater soil disturbance and lower soil moisture content. The relation between soil microbial activity versus soil moisture content even under different dry spells and soil organic carbon was better explained by correlation and regression studies (Table 7). There was a positive correlation between different microbial populations, microbial biomass carbon, nitrogen, as well as various enzymatic activities with soil moisture contents even under dry spells to the tune of 0.471 to 0.647 .

The application of $100 \%$ recommended NPK $+7.5 \mathrm{t} \mathrm{FYM}$ ha $\mathrm{a}^{-1}$ has exhibited significantly higher urease, dehydrogenase, acid phosphatase and alkaline phosphatase activity $(34.23 \mu \mathrm{g}$ $\mathrm{NH}_{4}-\mathrm{N} \mathrm{g} \mathrm{soil}{ }^{-1} \mathrm{hr}^{-1}, 179.56 \mu \mathrm{g} \mathrm{TPF} g$ soil ${ }^{-1} 24 \mathrm{hr}^{-1}, 37.91 \mathrm{~g} \mathrm{PNP} \mathrm{g} \mathrm{soil}^{-}$ ${ }^{1}$ and $36.58 \mathrm{~g}$ PNP g soil ${ }^{-1}$, respectively) due to significant enhancement of bacteria, fungi and actinomycetes $\left(55.86 \times 10^{5}\right.$, 
Table 6 : Soil enzymatic activities after harvest of second season crop, and grain and straw yield of finger millet as influenced by tillage and nutrient management practices

\begin{tabular}{|c|c|c|c|c|c|c|c|c|c|c|}
\hline \multirow[t]{2}{*}{ Treatment } & \multirow{2}{*}{$\begin{array}{l}\text { Urease } \\
\text { activity } \\
\left(\mu \mathrm{NHH}_{4}^{-} \mathrm{Ng}\right. \\
\left.\text { soil }^{-1} \mathrm{hr}^{-1}\right)\end{array}$} & \multirow{2}{*}{$\begin{array}{l}\text { Dehydrogen- } \\
\text { ase activity } \\
\text { ( } \mu \mathrm{gTPF}^{-1} \\
\text { soil }^{-1} 24 \mathrm{hr}^{-1} \text { ) }\end{array}$} & \multirow{2}{*}{$\begin{array}{l}\text { Acid } \\
\text { phosphatase } \\
\text { activity }(g \\
\left.\text { PNP g soil }^{-1}\right)\end{array}$} & \multirow{2}{*}{$\begin{array}{l}\text { Alkaline } \\
\text { phosphatase } \\
\text { activity }(g \\
\left.\text { PNP g soil }^{-1}\right)\end{array}$} & \multicolumn{3}{|c|}{ Grain yield (t ha ${ }^{-1}$ ) } & \multicolumn{3}{|c|}{ Straw yield $\left(\mathrm{t} \mathrm{ha}^{-1}\right)$} \\
\hline & & & & & 2014 & 2015 & Pooled & 2014 & 2015 & Pooled \\
\hline \multicolumn{11}{|l|}{ Tillage practices $(\mathrm{T})$} \\
\hline $\mathrm{T}_{1}$ : Conventional tillage-Sowing & 18.07 & 98.28 & 20.66 & 25.38 & 3.20 & 2.88 & 3.04 & 4.95 & 4.42 & 4.69 \\
\hline $\mathrm{T}_{2}$ : Minimum tillage-Sowing & 23.09 & 119.74 & 26.43 & 29.18 & 2.76 & 2.45 & 2.61 & 4.29 & 3.76 & 4.03 \\
\hline $\mathrm{T}_{3}$ : Zero tillage-Transplanting & 31.76 & 183.79 & 34.34 & 35.11 & 2.30 & 1.87 & 2.09 & 3.61 & 2.88 & 3.24 \\
\hline S.Em \pm & 0.65 & 4.18 & 0.66 & 0.86 & 0.08 & 0.08 & 0.06 & 0.14 & 0.12 & 0.09 \\
\hline CD at $5 \%$ & 2.54 & 16.41 & 2.59 & 3.36 & 0.30 & 0.31 & 0.18 & 0.54 & 0.48 & 0.30 \\
\hline \multicolumn{11}{|c|}{ Nutrient management practices (N) } \\
\hline $\begin{array}{l}N_{1}: 100 \% \text { recommended NPK } \\
\left(50: 40: 25 \mathrm{~kg} \mathrm{NPK} \mathrm{ha}^{-1}\right)\end{array}$ & 19.15 & 100.73 & 21.35 & 24.22 & 2.48 & 2.16 & 2.32 & 3.85 & 3.31 & 3.58 \\
\hline $\begin{array}{l}\mathrm{N}_{2}: 100 \% \text { recommended NPK }+^{-} \\
7.5 \mathrm{tFYM} \mathrm{ha}^{-1}\end{array}$ & 34.23 & 179.56 & 37.91 & 36.58 & 3.25 & 2.81 & 3.03 & 5.06 & 4.31 & 4.69 \\
\hline $\begin{array}{l}\mathrm{N}_{3}: \text { Horsegram residue mulch + } \\
100 \% \text { recommended NPK }\end{array}$ & 21.28 & 120.64 & 24.22 & 28.04 & 2.79 & 2.42 & 2.61 & 4.35 & 3.72 & 4.03 \\
\hline $\begin{array}{l}\mathrm{N}_{4}: \text { Horsegram residue mulch }+ \\
50 \% \text { recommended NPK }+25 \% \mathrm{~N} \\
\text { through } \mathrm{FYM}+\text { Azotobacterseed t }\end{array}$ & 24.64 & 142.32 & 27.48 & 32.10 & 2.37 & 2.10 & 2.24 & 3.68 & 3.23 & 3.45 \\
\hline $\begin{array}{l}\mathrm{N}_{5}: \text { Horsegram residue mulch }+ \\
\text { Fertilizers based on soil test results }\end{array}$ & 22.23 & 126.43 & 24.75 & 28.51 & 2.88 & 2.52 & 2.70 & 4.48 & 3.86 & 4.17 \\
\hline S.Em \pm & 0.67 & 4.07 & 0.68 & 0.80 & 0.06 & 0.09 & 0.05 & 0.10 & 0.13 & 0.08 \\
\hline CD at $5 \%$ & 1.95 & 11.88 & 2.00 & 2.33 & 0.19 & 0.25 & 0.15 & 0.30 & 0.38 & 0.24 \\
\hline \multicolumn{11}{|l|}{ Interaction ( $\mathrm{T} \times \mathrm{N})$} \\
\hline \multicolumn{11}{|l|}{$\mathrm{N}$ at same level of $\mathrm{T}$} \\
\hline S.Em \pm & 1.16 & 7.05 & 1.19 & 1.38 & 0.11 & 0.15 & 0.17 & 0.18 & 0.23 & 0.28 \\
\hline $\begin{array}{l}\mathrm{CD} \text { at } 5 \% \\
\text { T at same or different level of } \mathrm{N}\end{array}$ & NS & NS & NS & NS & NS & NS & NS & NS & NS & NS \\
\hline S.Em \pm & 1.22 & 7.56 & 1.25 & 1.50 & 0.13 & 0.15 & 0.17 & 0.21 & 0.24 & 0.27 \\
\hline CD at $5 \%$ & NS & NS & NS & NS & NS & NS & NS & NS & NS & NS \\
\hline
\end{tabular}

Note: CD-Critical difference, NS-Non significant

$31.65 \times 10^{4}, 18.35 \times 10^{3} \mathrm{CFU} g$ soil $^{-1}$, respectively) which was indicated by higher soil microbial biomass carbon $\left(572.0 \mu \mathrm{g} \mathrm{g} \mathrm{soil}{ }^{-1}\right)$ and nitrogen $\left(66.7 \mu \mathrm{g} \mathrm{g} \mathrm{soil}{ }^{-1}\right)$.

This was followed by horsegram residue mulch $+50 \%$ recommended NPK + $25 \% \mathrm{~N}$ through FYM + Azotobacter seed treatment, horsegram residue mulch + fertilizers based on soil test results and horsegram residue mulch $+100 \%$ recommended NPK. Whereas, significantly lower activity of enzymes, microbial population, microbial biomass carbon and nitrogen were found in $100 \%$ recommended NPK (19.15 $\mu \mathrm{g} \mathrm{NH}_{4}-\mathrm{N} \mathrm{g} \mathrm{soil}^{-1} \mathrm{hr}^{-1}, 100.73 \mu \mathrm{g}$ TPF g soil ${ }^{-1} 24 \mathrm{hr}^{-1}, 21.35 \mathrm{~g} \mathrm{PNP} \mathrm{g} \mathrm{soil}^{-1}, 24.22 \mathrm{~g} \mathrm{PNP} \mathrm{g} \mathrm{soil}^{-1}, 36.25$ $\times 10^{5}, 19.48 \times 10^{4}, 11.26 \times 10^{3} \mathrm{CFU}$ g soil ${ }^{-1}, 342.0 \mathrm{\mu g} \mathrm{g} \mathrm{soil}^{-1}$ and $39.9 \mathrm{\mu g} \mathrm{g} \mathrm{soil} \mathrm{I}^{-1}$, respectively). The higher microbial activity under $100 \%$ recommended NPK + 7.5 t FYM ha $^{-1}$ was mainly due to build up of soil organic matter content as witnessed by improved soil organic carbon $(0.60 \%)$ status. The regression models revealed that there was an increase in soil bacterial, fungal, actinomycetes population, soil microbial biomass carbon, nitrogen, urease, dehydrogenase, acid phosphatase and alkaline phosphatase activity by $150.78 \times 10^{5} \mathrm{CFU}$ g soil ${ }^{-1}, 91.10 \times 10^{4} \mathrm{CFU}$ g soil ${ }^{-1}, 49.19 \times 10^{3} \mathrm{CFU}$ g soil ${ }^{-1}, 1593.46 \mu \mathrm{g} \mathrm{g} \mathrm{soil}{ }^{-1}, 185.91 \mu \mathrm{g} \mathrm{g}$ soil $^{-1}, 99.03 \mu \mathrm{g} \mathrm{NH}_{4}-\mathrm{N}$ g soil ${ }^{-1} \mathrm{hr}^{-1}, 557.66 \mu \mathrm{g} \mathrm{TPF}$ g soil ${ }^{-1} 24 \mathrm{hr}^{-1}$, $103.42 \mathrm{~g} \mathrm{PNP} \mathrm{g} \mathrm{soil}^{-1}$ and $75.14 \mathrm{~g} \mathrm{PNP} \mathrm{g} \mathrm{soil}{ }^{-1}$ for every per cent increase in soil organic carbon (Table 7). The interaction between tillage and nutrient management practices was found to be non significant.

Conventional tillage was yielded significantly higher grain and straw yield of finger millet (3.04 and $4.69 \mathrm{tha}^{-1}$, respectively), (Table 6) which was attributed to better soil moisture content $(12.18,12.15$ and $11.34 \%$ at milking, physiological maturity and at harvest stages, respectively during 2014 and 11.97 and $11.52 \%$ at flowering stages, respectively during 2015) (Table 2) even under dry spells and higher soil infiltration rate, cumulative infiltration after harvest (Fig. 2), maximum water holding capacity (Fig. 3), lower 
Table 7 : Correlation and regression equations between soil physical, chemical and biological properties as influenced by tillage and nutrient management practices in finger millet

\begin{tabular}{|c|c|c|c|c|}
\hline Dependent variable (y) & Independent variable (x) & Corr. Coeff. (r) & Regression equation & $\mathbf{R}^{2}$ \\
\hline Infiltration rate & Bulk density at $0-15 \mathrm{~cm}$ & -0.912 & $Y=31.73-12.60 x$ & 0.832 \\
\hline Cumulative infiltration & & -0.920 & $Y=70.29-26.89 x$ & 0.846 \\
\hline Soil penetration resistance at $0-15 \mathrm{~cm}$ & & 0.859 & $Y=-2336.33+2804.77 x$ & 0.737 \\
\hline Infiltration rate & Bulk density at $15-30 \mathrm{~cm}$ & -0.917 & $Y=31.66-11.92$ & 0.841 \\
\hline Cumulative infiltration & & -0.925 & $Y=70.12-25.45 x$ & 0.855 \\
\hline Soil penetration resistance $15-30 \mathrm{~cm}$ & & 0.824 & $Y=-3540.58+3728.09 x$ & 0.679 \\
\hline Infiltration rate & Bulk density at $30-45 \mathrm{~cm}$ & -0.878 & $Y=42.77-18.34 x$ & 0.770 \\
\hline Cumulative infiltration & & -0.869 & $Y=92.70-38.43 x$ & 0.755 \\
\hline Soil penetration resistance $30-45 \mathrm{~cm}$ & & 0.895 & $Y=-9407.35+7517.35 x$ & 0.801 \\
\hline MWHC (\%) at $0-15 \mathrm{~cm}$ & Soil organic carbon (\%) & 0.924 & $Y=6.01+66.53 x$ & 0.854 \\
\hline MWHC (\%) at $15-30 \mathrm{~cm}$ & & 0.924 & $Y=5.38+59.17 x$ & 0.854 \\
\hline MWHC (\%) at $30-45 \mathrm{~cm}$ & & 0.657 & $Y=21.07+22.59 x$ & 0.432 \\
\hline Bacterial population & Mean soil moisture & 0.614 & $Y=-3.46+3.69 x$ & 0.377 \\
\hline Fungal population & content during dry & 0.599 & $Y=-3.46+2.15 x$ & 0.359 \\
\hline Actinomycetes population & period at 08-12-2014 & 0.587 & $Y=-0.29+1.11 x$ & 0.345 \\
\hline Soil microbial biomass carbon & & 0.538 & $Y=0.99+32.92 x$ & 0.289 \\
\hline Soil microbial biomass nitrogen & & 0.538 & $Y=0.11+3.84 x$ & 0.289 \\
\hline Urease activity & & 0.471 & $Y=1.40+1.76 x$ & 0.222 \\
\hline Dehydrogenase activity & & 0.576 & $Y=-28.86+12.56 x$ & 0.331 \\
\hline Acid phosphatase activity & & 0.463 & $Y=3.79+1.80 x$ & 0.215 \\
\hline Alkaline phosphatase activity & & 0.606 & $Y=7.42+1.73 x$ & 0.367 \\
\hline Bacterial population & Mean soil moisture & 0.647 & $Y=-13.15+4.41 x$ & 0.419 \\
\hline Fungal population & content during dry & 0.633 & $Y=-9.20+2.58 x$ & 0.400 \\
\hline Actinomycetes population & period at 31-10-2015 & 0.620 & $Y=-3.25+1.33 x$ & 0.384 \\
\hline Soil microbial biomass carbon & & 0.572 & $Y=-89.82+39.75 x$ & 0.327 \\
\hline Soil microbial biomass nitrogen & & 0.572 & $Y=-10.48+4.63 x$ & 0.327 \\
\hline Urease activity & & 0.504 & $Y=-3.61+2.14 x$ & 0.254 \\
\hline Dehydrogenase activity & & 0.610 & $Y=-62.96+15.12 x$ & 0.372 \\
\hline Acid phosphatase activity & & 0.495 & $Y=-1.33+2.18 x$ & 0.245 \\
\hline Alkaline phosphatase activity & & 0.634 & $Y=3.08+2.05 x$ & 0.401 \\
\hline Bacterial population & Soil organic carbon (\%) & 0.871 & $Y=-31.90+150.78 x$ & 0.759 \\
\hline Fungal population & & 0.879 & $Y=-21.58+91.10 x$ & 0.773 \\
\hline Actinomycetes population & & 0.899 & $Y=-10.71+49.19 x$ & 0.809 \\
\hline Soil microbial biomass carbon & & 0.905 & $Y=-378.46+1593.46 x$ & 0.819 \\
\hline Soil microbial biomass nitrogen & & 0.905 & $Y=-44.15+185.91 x$ & 0.819 \\
\hline Urease activity & & 0.919 & $Y=-25.79+99.03 x$ & 0.844 \\
\hline Dehydrogenase activity & & 0.888 & $Y=-148.21+557.66 x$ & 0.789 \\
\hline Acid phosphatase activity & & 0.925 & $Y=-25.18+103.42 x$ & 0.855 \\
\hline Alkaline phosphatase activity & & 0.913 & $Y=-8.12+75.14 x$ & 0.834 \\
\hline
\end{tabular}

All the soil physical, chemical and biological properties are analysed after second season finger millet

bulk density (Table 3) and lower soil penetration resistance (Fig. 2) resulted in better conservation of moisture through infiltration of rain water into soil profile as compared to minimum tillage (2.61 and $4.03 \mathrm{t} \mathrm{ha}^{-1}$, respectively). These findings are supported by Romaneckas et al. (2009) who observed higher sugar beet root yield under conventional tillage due to lower soil penetration resistance and lower soil bulk density as compared to zero tillage. Saha et al. (2010) noticed that increase in maize and mustard yields under conventional system with residue was associated with better root growth and increased water use by the crop. Similarly, decrease in yields under zero tillage might be attributed to increased soil strength and consequent retardation in root growth and reduction in water utilization from deeper layers. Whereas, zero tillage had recorded significantly lower grain and straw yield (2.09 and $3.24 \mathrm{tha}^{-1}$, respectively) because of above poor soil physical properties. These findings corroborate with the results of Alvarez and Steinbach (2009) and Guan et al. (2014) who recorded lower grain yields in zero tillage because of poor soil infiltration rate, hydraulic conductivity, higher bulk density and lower soil porosity.

Application of $100 \%$ recommended NPK $+7.5 \mathrm{tFYM} \mathrm{ha}^{-1}$ produced significantly higher grain and straw yield of finger millet 
(3.03 and $4.69 \mathrm{t} \mathrm{ha}^{-1}$, respectively) and was attributed to better moisture conservation at various growth stages (Table 2) and due to better release of nutrients due to improved soil microbial population, microbial biomass carbon, microbial biomass nitrogen recorded (Table 5), which helped in faster decomposition of FYM through mineralization with the aid of increased enzymatic activities viz., urease, dehydrogenase, acid phosphatase and alkaline phosphatase enzymes (Table 6). These results are in confirmation with the findings of Prabhakar Reddy et al. (2007), Aariff Khan et al. (2011) and Basha et al. (2017). Schulz (2004) suggested that addition of farmyard manure increase microbial biomass, biological activities and soil enzyme activities. Enzymes in soil, especially dehydrogenase enzymes, are highly associated with the microbial biomass, which in turn affects the decomposition of organic matter and release of $\mathrm{CaCO}_{3}$. The next higher yield was observed in horsegram residue mulch + fertilizers based on soil test results (2.70 and $4.17 \mathrm{t} \mathrm{ha}^{-1}$, respectively), which was found on par with horsegram residue mulch $+100 \%$ recommended NPK (2.61 and $4.03 \mathrm{t} \mathrm{ha}^{-1}$, respectively) as compared to $100 \%$ recommended NPK alone (2.32 and $3.58 \mathrm{t} \mathrm{ha}^{-1}$, respectively). Whereas, significantly lower grain and straw yield were observed in horsegram residue mulch $+50 \%$ recommended NPK $+25 \% \mathrm{~N}$ through FYM + Azotobacter seed treatment (2.24 and 3.45 tha ${ }^{-1}$, respectively). Application of horsegram residue mulch + fertilizers based on soil test results, recorded higher grain and straw yields next to $100 \%$ recommended NPK $+7.5 \mathrm{tFYM} \mathrm{ha}{ }^{-1}$, and was found on par with horsegram residue mulch $+100 \%$ recommended NPK due to better soil moisture conservation through mulching (Table 2), better soil infiltration rate, cumulative infiltration, lower soil bulk density, higher maximum water holding capacity (Fig. 2, 3 and Table 3) and soil microbial as well as enzymatic activities (Table 5, 6). Whereas, application of horsegram residue mulch $+50 \%$ recommended NPK $+25 \% \mathrm{~N}$ through FYM + Azotobacter seed treatment had recorded significantly lower grain and straw yield of finger millet. These results corroborate with the findings of Nigade and More (2013) who quoted that application of $50 \%$ recommended dose of fertilizers in finger millet lead to $26.5 \%$ decrease in grain and straw yield as compared to $100 \%$ recommended dose of fertilizers.

Improved soil physical properties viz., higher soil infiltration rate, cumulative infiltration, lower soil penetration resistance, bulk density were found in conventional tillage. Whereas, other parameters like higher soil moisture content under dry spells, higher maximum water holding capacity were observed under zero tillage. Apart from these parameters, soil chemical and biological properties such as higher soil organic carbon, bacterial, fungal, actinomycetes population, soil microbial biomass carbon, nitrogen, urease, dehydrogenase, acid phosphatase and alkaline phosphatase enzymatic activity were realized under zero tillage. Among different nutrient management practices, application of $100 \%$ recommended NPK
$+7.5 \mathrm{t} \mathrm{FYM} \mathrm{ha-1} \mathrm{had} \mathrm{showed} \mathrm{improvement} \mathrm{in} \mathrm{all} \mathrm{above} \mathrm{given} \mathrm{soil}$ physico-chemical and biological properties and gave significantly higher grain and straw yields. Even though the soil moisture content and soil biological parameters were better under zero tillage, however, the yields were lower due to unfavourable soil physical conditions viz., lower soil infiltration rate, cumulative infiltration, higher bulk density, soil compaction and soil penetration resistance at different depths. These factors have taken upper hand and resulted in lower grain yield under zero tillage.

\section{Acknowledgments}

Authors sincerely acknowledge the AICRP on Dryland Agriculture, University of Agricultural Sciences, GKVK, Bengaluru for providing all the facilities for this field and laboratory studies and INSPIRE Fellowship given by Department of Science and Technology, Ministry of Science and Technology, Govt. of India for pursuing Ph.D related research work of first author.

\section{References}

Aariff Khan, M.A., K. Rajamani and A.P.K. Reddy: Nutrient content, uptake, soil enzymatic activity and available nutrient status of sweet sorghum as influenced by nutrient management in agri-silvi culture system. Indi. J. Dryland Agricul. Res. Develop., 26, 83-89 (2011).

Alvarez, R. and H.S. Steinbach: A review of the effects of tillage systems on some soil physical properties, water content, nitrate availability and crops yield in Argentine. Soil Till. Res., 52, 156-160 (2009).

Basha, S.J., R. Basavarajappa, G. Shirnalli and H.B. Babalad: Soil microbial dynamics and enzyme activities as influenced by organic and inorganic nutrient management in vertisols under aerobic rice cultivation. J. Environ. Biol., 38, 131-138 (2017).

Brady, N.C. and R.R. Weil: Nature and Properties of Soils. $14^{\text {th }}$ Edn., Pearson Education Inc. Prentice Hall. New Delhi (2008).

Carter, M.R.: Ninhydrin-reactive N released by the fumigation extraction method as a measure of microbial biomass under field conditions. Soil Biol. Biochem., 23, 139-143 (1991).

Casida, L.E., D. Klein and T. Santoro: Soil dehydrogenase activity. Soil Sci., 98, 371-376 (1964).

Chandel, S., D. Tripathi and and R. Kakar: Soil health assessment under protected cultivation of vegetable crops in North West Himalayas. J. Environ. Biol., 38, 97-103 (2017).

Eivazi, F. and M.A. Tabatabai: Phosphatases in soils. Soil Biol. Biochem., 9, 167-177 (1977).

Gomez, K.A. and A.K. Gomez: Statistical Procedures for Agricultural Research. $2^{\text {nd }}$ Edn., John Wiley and Sons, New York (1984).

Guan, D., M.M. Al-Kaisi, Y. Zhang and L.D.W. Tan: Tillage practices affect biomass and grain yield through regulating root growth, rootbleeding sap and nutrients uptake in summer maize. Field Crop Res., 157, 89-97 (2014).

Hugh, J., J.Y. Beckie, A. Leeson, T.L.M. Gordon and A.B. Clark: Risk assessment of weed resistance in the Canadian prairies. Weed Tech., 22, 741-746 (2008).

Jackson, M.K.: Soil Chemical Analysis. Prentice-Hall. Nc. Engle wood cliffs, New Jersey (1973). 
Kar, G. and A. Kumar: Evaluation of post-rainy season crops with residual soil moisture and different tillage methods in rice fallow of eastern India. Agril. Water Mangt., 96, 931-938 (2009).

Liu, E., C. Yan, X. Mei, Y. Zhang and T. Fan: Long-term effect of manure and fertilizer on soil organic carbon pools in dryland farming in northwest China. Plos One, 8, 10-20 (2013).

Manivannan, S., M. Balamurugan, K. Parthasarathi, G. Gunasekaran and L.S. Ranganathan: Effect of vermicompost on soil fertility and crop productivity - beans (Phaseolus vulgaris). J. Environ. Biol., 30, 275-281 (2009).

Michael, A.M.: Irrigation: Theory and Practices. $2^{\text {nd }}$ Edn., Vikas Publishing House Pvt. Ltd., New Delhi (2009).

Nigade, R.D. and S.M. More: Performance of finger millet varieties to different levels of fertilizer on yield and soil properties in submontane zone of Maharashtra. Int. J. Agri. Sci., 9, 256-259 (2013).

Parr, J.R. and A.R. Bertrand: Water infiltration into soils. Adv. Agron., 12, 311-363 (1960).

Piper, C.S.: Soil and PlantAnalysis. Inter. Sci. Pub. Inc., New York (1966).

Prabhakar Reddy, J., M. Umadevi, P. Chandrasekhar Rao and V.B. Bhanumurthy: Effect of fly ash and FYM on soil enzymatic activities in a saturated Inceptisol under incubated conditions. J. Res. Angrau, 35, 31-40 (2007).

Rajan, K., S.S. Singh and N. Subash: Effect of nursery raising techniques of Boro rice on plant growth and soil physical properties. Oryza, 48, 137-141 (2011).

Romaneckas, K., R. Romaneckiene, E. Sarauskis, V. Pilipavicius and A. Sakalauskas: The effect of conservation primary and zero tillage on soil bulk density, water content, sugar beet growth and weed infestation. Agron. Res., 7, 73-86 (2009).

Saha, S., D. Chakraborty, A.R. Sharma, R.K. Tomar, S. Bhadraray, U. Sen, U.K. Behera, T.J. Purakayastha, R.N. Garg and N. Kalra: Effect of tillage and residue management on soil physical properties and crop productivity in maize (Zea mays)-Indian mustard (Brassica juncea) system. Indi. J. Agril. Sci., 80, 679-685 (2010).

Schulz, E.: Influence of site conditions and management on different soil organic matter (SOM) pools. Archiv. Agron. Soil Sci., 50, 33-48 (2004).

Sessiz, A., A. Alp and S. Gursoy: Conservation and conventional tillage methods on selected soil physical properties and corn (Zea mays L.) yield and quality under cropping system in Turkey. Bulgarian J. Agric. Sci., 16, 597-608 (2010).

Singh, R.C., S. Lenka and C.D. Singh: Conservation tillage and manure effect on soil aggregation, yield and energy requirement for wheat (Triticum aestivum) in vertisols. Indi. J. Agril. Sci., 84, 267-271 (2014).

Singh, V.P., K.K. Barman, P.K. Singh, R. Singh and A. Dixit: Managing weeds in rice (Oryza sativa)-wheat (Triticum aestivum)-greengram (Vigna radiata) system under conservation agriculture in black cotton soils. Indi. J. Agril. Sci., 87, 739-45 (2017).

Spehia, R.S., B.C. Thakur and J.N. Raina: Effect of in-situ conservation practices on soil properties and yield of broccoli under rainfed conditions of mid hill zone of Himachal Pradesh. Indian J. Hort., 69, 129-132 (2012).

Subbiah, B.V. and G.L. Asija: A rapid procedure for the determination of available nitrogen in soil. Curr. Sci., 31, 196-198 (1956).

Teodor, R., P.I. Moraru, O. Ranta, I. Drocas, I. Bogdan, A.I. Pop and M.L. Sopterean: No-tillage and minimum tillage-their impact on soil compaction, water dynamics, soil temperature and production on wheat, maize and soybean. Bulletin UASVM Agri., 68, 318-323 (2011).

Zaredost, F., D. Hashemabadi, M.B. Ziyabari, A.M. Torkashvand, B. Kaviani, M.J. Solimandarabi and M. Zarchini: The effect of phosphate bio-fertilizer (Barvar-2) on the growth of marigold. $J$. Environ. Biol., 35, 439-443 (2014). 